\title{
A Sociological Overview of Individual Instrument Lessons in the New Normal
}

\author{
DOI: $10.26466 /$ opus.885009
}

\author{
Elçin Ergin Talaka * \\ * Lecturer Ph.D, Kastamonu University, Fine Arts and Design Faculty, Kastamonu, Turkey. \\ E-Mail: elcin06@gmail.com \\ ORCID: $\quad \underline{0000-0002-2766-1285}$
}

\begin{abstract}
The Covid19 pandemic, which has affected the whole world, has increasingly affected all areas of social life, especially in the field of health. Although the health area is partially prepared for the process due to its natural structure, many difficulties are encountered. This process, in which all aspects of the education field are caught unprepared, are tried to be overcome with as little damage as possible. In this process, higher education levels of education try to manage the process by putting their distance education systems into use urgently. Although students experience individual technical difficulties in the teaching of theoretical courses, they can overcome their deficiencies by watching the repetition of the course. It can be said that there are a lot of problems in the applied areas of art-based programs. Individual instrument lessons in music education is one of these application areas. In addition to theoretical and technical studies, it is thought that the distance education system is not the solution in instrument training based on the master-apprentice tradition by imitating the student's teacher. In addition to teacher-student cooperation, the current system can be structured by taking such lessons into consideration in order for the process to function properly. In this study, the difficulties that have been observed and experienced since the beginning of the pandemic were tried to be evaluated from a sociological perspective and the difficulties in individual instrument lessons were tried to be defined.
\end{abstract}

Keywords: Pandemic, individual instrument, distance education, practical lessons. 


\section{Yeni Normal İçerisinde Bireysel Çalgı Derslerine Sosyolojik Bir Bakış}

\section{Öz}

Tüm dünyayı etkisi altına almış olan Covid19 pandemisi başta sağlık alanı olmak üzere sosyal hayata ilişkin tüm alanları artan bir şekilde etkisi altına almıştır. Sağlık alanı doğal yapısı gereği sürece kısmen hazırlıkl olsa da birçok zorluk yaşanmaktadır. Ĕ̆itim alanının ise tüm boyutları hazırlıksız yakalandığı bu süreç elden geldiği ölçüde az zararla atlatılmaya çalışılmaktadır. Bu süreçte Eğitimin yüksek öğrenim kademeleri, kendi uzaktan eğitim sistemlerini acilen kullanıma sokarak süreci yönetmeye çalışmaktadır. Teorik derslerin işlenişinde öğrenciler bireysel teknik olanaksılzklar yaşasa da ders tekrarlarmı izleyerek eksiklerini giderebilmektedir. Sanat içerikli programları uygulamalı alanlarında ise fazlasıyla sorun yaşandığı söylenebilir. Müzik ĕ̆itiminde bireysel çalgı dersleri bu uygulama alanlarından biridir. Teorik ve teknik çalışmaların yanında öğrencinin öğretmenini taklit ederek, usta-çırak geleneği temel alınan çalgı eğitiminde uzaktan eğitim sisteminin çözüm olmadı̆̆ düşünülmektedir. Sürecin sağlıkl işleyebilmesi için öğretmen-öğrenci iş birliğinin yanında mevcut sistem bu tarz dersleri de göz önüne alarak yapılandırılabilir. Bu çalışmada, pandeminin başından itibaren gözlemlenen, yaşanan sıkıntılar sosyolojik bir bakış açısı ile değerlendirmeye çalışılarak bireysel çalgı dersleri içerisindeki zorluklar tanımlanmaya çalışılmıştır.

Anahtar Kelimeler: Pandemi, bireysel çalgı, uzaktan eğitim, uygulamalı dersler. 


\section{Introduction}

The epidemic that started in the middle of 2019 had a rapid impact all over the world and started to show its adverse effects, first in health and then in other fields, spreading rapidly with a high mortality rate. After a long time, coming face to face with such a reality has become the most challenging test of humanity in the 21st century by affecting the way of life and activities in education, economy, politics and all other individual and social spheres, and has become an insurmountable one. The pandemic that affects all sectors from $\mathrm{A}$ to $\mathrm{Z}$ is briefly: "The occurrence of a disease among a certain group of people in more cases than expected for a certain period of time" (Özoğlu, 2020). Education and health were the two most affected areas in this process. It is possible to consider the effects of the Covid 19 pandemic on education from different angles as of its causes, consequences and current situation; It would be beneficial to look at this situation in terms of "globalization", which is the main disease of our age. This new economy, where commodity relations are increasingly spreading, local markets are articulated with foreign markets, traditional forms of production are destroyed, production serves the purpose of profit and capital is dominant worldwide, globalization as a system in which it introduces its own system into every market it enters; It has directly affected the education sector as financial resources, manpower and social inequality. The fact that the education system is unprepared for emergencies and the necessary budget is not allocated to sector employees, and the insufficiency of the infrastructure and products used for educational purposes deeply affect both teachers and students. In addition to this interaction, it is thought that during the pandemic period, teaching lessons in all dimensions of education remotely creates problems in the access of students to lessons with equal opportunities and in the parts of the applied fields that require skill and movement. Students can have many sub-problems and dynamics affecting in this process. However, the technical impossibilities of the student or the noncompliance of the applications with the nature of the field may turn into difficult problems in the future. From this point of view, it is thought that making realistic and functional plans by defining the process correctly and examining the instrument training under the social conditions of teacher 
and student interaction will ease the process. The aim of the study is to examine the individual instrument education in the epidemic process from a sociological perspective. The results have been reached by using the experiences observed and interpreted since the beginning of the pandemic and document analysis.

\section{Education and School as a Social Institution}

Education, with its best-known definition, is the desired and permanent behavior change process. From the point of view of educational sciences, this definition describes the changes that can be observed directly with behavior. According to Gökalp (1976), education is the giving of ideas and feelings to the people who are educated in a society, and the adaptation of the individual to the culture is provided by education and the adaptation to technology.

The sociological dimensions of education include concepts such as social stratification, equality of opportunity in education, knowledge society, consumption culture, leisure time and school, and serious changes are observed in the structure of education during the epidemic period (Bayhan, 2015). With the epidemic, conventional methods and contents applied for years in the application areas of education have been replaced by materials with short content, and the boundaries between theory and practice have begun to disappear. During the pandemic process, the relationships that should be between the actors of these institutions become irregular and some social roles and functions are impaired. The pandemic effects that cause these degradation and irregularities are thought to be:

- Interruption of the relationship between society and students.

- Restriction of freedom in the field of education.

- Incomplete gains in social roles between teacher-student, studentstudent.

- Mixed perceptions of using time efficiently

- Psychological pressure on social life.

- Restriction in social learning capacity. 
- Limitations in socialization capacity (cultural Problems in identifying the mechanisms and social control mechanisms with their own internal control mechanisms (non-internalization).

- Lacks in social interaction (not using communication tools such as language, symbol, movement).

According to Karakaş (2020), distance education and technological experiments were implemented as a measure to overcome the difficulties during the pandemic period. Education actors, without giving up the advantages of face-to-face education, have tended to look for ways to benefit from the opportunities and facilities of distance education. However, this situation is different for the application steps of music education.

With its unique system and different structure from other fields, music is a science that unites social life and balances relations between people in a non-normative way with its own rules. Perhaps this feature is soothing. Instrument education is also a branch of music science-music educationmusic art adorned with these features. In instrument education, the individual gains a systematic technical and musical skills in an instrument, while at the same time gaining a wide range of performance knowledge with both world music and works of his own culture. The important point here is that instrumental skills are mainly practical as well as their theoretical gains. Instrument education is a holistic design of teacher-student communication and interaction with its individualized, student-specific structure. The sources that teachers use when transferring information to students according to certain schools and within a certain systematic may differ. In face-to-face education, the student demonstrates his performance in the lesson by listening to himself by looking at the note and by watching and correcting his technique. In addition, the masterapprentice discipline, which has been maintained as a tradition from the past to the present, is a must for this training. Whether it is a western or Turkish musical instrument, due to the nature of playing the instrument, students watch their teachers, try to imitate the teacher's technique and try to play it like him. In this way, while developing his musicality and technical skills, he can reach a certain level in the instrument with the systematic theoretical content and corrections given by the teacher. From 
this point of view, being face-to-face is an important condition for the healthy conduct of instrument training because instrument training is defined as the instrument teaching process, which is carried out in a programmatic way in line with "pre-determined" purposes, based on the face-to-face training approach and organized in accordance with the characteristics of the individual" (Yalçınkaya, Eldemir and Sönmezöz, 2014, p.1584). In addition, teachers and students have some expectations from each other in instrument training. According to Girgin (2015), these expectations are; mutual love and respect, students playing the works with the appropriate technique and feeling the music, being willing, coming to class by working and organizing their own study strategies; creating a suitable physical environment for study and study, encouragement and so on. countable. If these expectations are not met, communication will not be healthy and the process will be difficult for both teachers and students. In addition to student-teacher expectations, another factor affecting success is seen as student motivation. According to Özmenteş (2013, p.328), who stated that students have intrinsic and extrinsic motivation in instrument success, "attributing their failure in their performance to their own abilities or reasons they think they cannot control is a factor that negatively affects their motivation towards the instrument".

When we look at the instrument training in the distance education process: the possibility of students attending classes on a computer, tablet or phone, being with their families during the pandemic process and not having an internet connection where they are, decreases participation in lessons especially for students who have just started instrumental education and the current system is inadequate to gain basic behaviors. It can cause students to lose their motivation. In addition, it is thought that technical problems and conducting the lessons under different conditions than they should not only affect the motivation of the students, but also affect their success negatively and may lead to situations such as apathy, ignoring, absenteeism and not following the lesson after a while. According to Birkök (2000,p.38), distance education is seen as a positive development in terms of transferring culture to different regions through broadcasting tools and providing equal opportunity in education. However, this method is insufficient especially for emergencies and 
applied issues. As a matter of fact, as Yild1z Vural (2020, p.563) stated in the 6th month evaluation report of the Turkish Medical Association on global inequality during the pandemic period "practices that define education as the right of citizenship do not take into account the situation of those living in inadequate conditions". Considering that instrument training is a difficult process that requires high-level skills, it is thought that the technical difficulties experienced in distance education lessons will affect this area more than other areas, and students may fail due to inadequate conditions and may not gain the technical skills required in the instrument.

\section{Conclusion}

During the pandemic period, it seems that the only solution is to use various methods to minimize these difficulties in instrument lessons that are held or to be done remotely due to the existing risks and to ensure that the lessons are passed efficiently by identifying the individual difficulties experienced by the students and ensuring that students receive an efficient instrument education with interventions to the extent that the teacher can do. For example, it should be ensured that students are included in a standard practice for individual instrument lessons, and since there will be many deficiencies in the course and skills in the participation of students on the phone, technical infrastructure should be provided for practical lessons, at least by state or local governments. In addition, the use of three-dimensional instrument training programs designed with various programs can be made available to students free of charge during the pandemic process. In these programs that will enable students to learn on their own, it is thought to be a temporary solution, as there will be no situations to ask questions to the teacher or to notice when they do wrong.

In order to fulfill the social functions lost by the school during the pandemic period, weekly or monthly meetings with the advisors and the lecturers of each course will ensure both group interaction and strengthen the social ties between student-teacher, student-student and determine the social and educational needs experienced during the pandemic process will also allow. 
In addition to the above effects, they are psychological situations in which the pandemic creates another impact dimension. Considering that being in a group and the quality of group membership affect the behavior of the individual in society, it will not be possible to expect healthy technical and musical behaviors from students who have difficulties in terms of individual instrument during the education process. Karakaş (2020) expects a change in classroom structure, teacher-student relations and assessment-evaluation system styles at the end of the process and thinks that new normals will emerge for all these stages, but will not be easy.

It is a fact that all the mechanisms that make up the social system, such as education, economy, politics, health, etc., work in full capacity and cooperation. Possible bad situations require management with serious foresight. The applications of the distance education method leave aside the pragmatist aspect of the education and defer the principle of "student relativity" due to the shortcomings for the courses and the contradiction of the nature of the application, behavioral limitations and the inability to control students, and accepts each student at the same level and skill for each course.

\section{References}

Bayhan, V. (2015). A new model in the field of application of educational sociology: School sociologist and his duties. Journal of Sociology, 30(1), 255-274.

Birkök, M. C. (2000). A Conceptual Analysis of Distance Educational Functions and Perspectives in Sociology. Turkish Online Journal of Distance Education, 1(2).

Girgin, D. (2015). Expectations from teacher and student perspectives in instrument training in music education departments. Education Sciences, 10(3), 169-183.

Gökalp, Z. (1976). Articles I. Ankara: Ministry of Culture Publications.

Karakaş, M. (2020). The multidimensional sociology and new normal issue of the Covid-19 pandemic. Istanbul University Journal of Sociology, 40(1), 541-573. 
Özmenteş, S. (2013). Student motivation and performance in instrument education: Journal of Education and Teaching Research, 2(2), 320-331.

Özoğlu, M. (2020). Pandemic glossary. wwww.tr.euronews. Date of Access: 29 December 2020.

Yalçınkaya, B. Eldemir, A. C. and Sönmezöz, F. (2014). Evaluation of music teacher candidates' attitudes towards individual instrument lesson. Turkish Studies, 9(2), 1583-1595.

\section{Citation Information}

Ergin Talaka, E. (2021). A sociological overview of individual instrument lessons in the new normal. OPUS-International Journal of Society Research, 18(41), 3705-3713. DOI: 10.26466/opus.885009. 